Article

\title{
The Reformers and Tradition: Seeing the Roots of the Problem
}

\section{R. Ward Holder}

Theology Department, Saint Anselm College, Manchester, NH 03102, USA; wholder@anselm.edu

Academic Editor: Christopher Metress

Received: 10 February 2017; Accepted: 15 May 2017; Published: 31 May 2017

\begin{abstract}
Challenges the ideal of scripture vs. tradition as a manner of separating Protestants from Catholics in the early modern period, to argue instead that historians should be setting out a continuum of continuity with the medieval inheritance, and considering our typologies of the Reform movements against that. Then, as we teach the Christian Intellectual Tradition, we can see both genealogical and influential links across the eras, and present a better picture of what was going on in the Era of the Reformations, and through that, come to a greater understanding of the human condition.
\end{abstract}

Keywords: scripture; tradition; Reformation(s); Reformers; Protestant; Catholic; radical; Martin Luther; John Calvin

In 1517, on the Vigil of All Saints Day, Martin Luther posted his 95 Theses on the door of the church in Wittenberg, and changed history forever. Actually, many of these facts can be challenged-Luther may or may not have posted the 95 Theses, for instance. But for teaching the Christian Intellectual Tradition, this is truly one of those "red letter days." That's why all early modernists worth their salt are going to spend the remainder of this year and next talking about how their research throws particularly bright light on Martin Luther, and the Reformation. Early modern or Reformation scholarship is going to be all Luther, all the time, for the remainder of 2016 and 2017.

In doing so, we will trot out a number of old chestnuts, because as we have found, the old ideas got to be old ideas because people liked them and could remember them. We will talk about the three Reformation solas—sola fide, sola gratia, and sola scriptura (Vanhoozer 2016). ${ }^{1}$ We will impress (or bore) our students by explaining the meaning of the ablatives and how that gives just the right amount of nuance to these formulae. We will turn to the 17th century for a description of the Reformation-Ecclesia Reformata, Semper Reformanda-and consider that this was trying to capture a dynamism that sought to argue with the classicism of medieval Catholicism (Benedict 2002).

At some point we will arrive at the difference between scripture and tradition. Again, we will trot out this commonplace because although we know it not to be nuanced, we see great explanatory powers in bumper-sticker history. And if it's not nuanced, it's also not wholly wrong, we tell ourselves. It is easy to find Luther or Calvin deriding the use of tradition. For instance, in his dedicatory letter to Pope Leo X that introduced The Freedom of the Christian, Luther claimed that he would only accept that which came from clear reason and the word of God (Luther 1962). Similarly, Calvin wrote, "Let this be a firm principle: No other word is to be held as the Word of God, and given place as such in the church,

1 Kevin Vanhoozer is bringing out a book, Biblical Authority after Babel: Retrieving the Solas in the Spirit of Mere Protestant Christianity. Grand Rapids: Brazos Press, 2016, that concentrates on the traditional "sola" statements. 
than what is contained first in the Law and the Prophets, then in the writings of the apostles; and the only authorized way of teaching in the church is by the prescription and standard of his Word." ${ }^{2}$

But it's not only Protestants of various stripes who have clung to the idea of scripture and tradition as a mnemonic device for understanding the two sides of the Reformation struggles. Fr. George Tavard, in his Holy Writ and Holy Church, sought to argue that the two were inseparable, while always accepting that these two divisions illustrated the sides of Reformation faith (Tavard 1959).

But surely things have changed: hasn't the aim of modern pedagogy and historiography pointed toward greater sophisitication? Well, perhaps. There have been studies that look at the Protestant Reformers' use of the tradition. All too frequently, these are simply laundry lists of the material that Reformers used from patristic sources. Out of that, we get brilliant studies that feature terms like "use of," or even more simply, "and": "Luther's use of the fathers," "Calvin and Augustine," etc. But actually, things have not changed that much. In these recent studies, it is still possible to find scholars holding on to the idea that Reformers simply read the scriptures as the basic method of preaching, commenting upon scripture, and construction of theological works. An extraordinary example was published only a few years ago that found all of the Reformers were bound by the pure teachings of the Scriptures. The author found the Reformation to have been an extraordinarily biblical event.

The Protestant Reformation was a revolution in the original scientific sense of that word: the return of a body in orbit to its original position. It was never the desire of Luther to start a new church from scratch. He and the other reformers who followed in his tracks wanted to re-form the one, holy, catholic and apostolic church on the basis of the Word of God and to do so by returning to the historic faith of the early church as they found it set forth in the pure teachings of the Scriptures. This led to a fundamental reorientation in Christian theology. Luther's re-discovery of justification by faith alone, Zwingli's insistence on the clarity and certainty of the Bible, Calvin's emphasis on the glory and sovereignty of God[,] and the Anabaptist quest for a true visible church all found expression in numerous new confessions, catechisms, commentaries, liturgies, hymns, martyrologies and church orders. Like a great earthquake that continues to generate seismic aftereffects long after the first shock is over, the Reformation set in motion a revolution in religious life the effects of which are still being felt half a millenium later. (George 2011)

While this is an extraordinary example of a tendency from which modern historiographical directions have attempted to part company, it demonstrates that this tendency still exists. For some, the issue is simply that the Reformers rediscovered the pure Bible. That tendency worked on both sides of the Protestant and Catholic divide. While Protestants could smugly claim to hold to the purity of the scriptural witness, Catholics could look down their noses at a renegade band that refused to admit the ways that they had been formed by tradition, and pretended to be the church.

Historiographically, this was helpful. Academics, and American academics in particular, pretend to love freedom. We proclaim in a variety of ways that the search for truth must be unhindered and unchained by any extraneous constraints, and any pre-conceived notions. That's what we say. But in point of fact, that kind of scholarship, which always begins with a blank slate, is extraordinarily difficult. There is nothing more terrifying to a working scholar than a blank piece of paper, or in this age, a truly blank Google doc. So we use those principles and axioms we believe either to have been long proven, or so self-evident that their truth lies beyond proof. One such is the division between scripture and tradition, an important marker for setting out the division between Protestants and Catholics in the time of the Reformations.

2 (Calvin 1960; Calvin 1895). CO 2.850. "Esto igitur hoc firmum axioma, non aliud habendum esse Dei verbum cui detur in ecclesia locus, quam quod lege primum et prophetis, deinde scriptis apostolicis continetur, nec alium esse rite docendi in ecclesia modum nisi ex eius verbi praescripto et norma." 
But ... does that historical theory really capture the essence of the moment? Did the Reformers really innovate a new religion that avoided all traditional material culture and traditional belief and practice? If so, why did they argue amongst themselves about the proper degree of departure from Rome? So, in this effort at thinking about our pedagogy, I want to challenge the ideal of scripture vs. tradition as a manner of separating Protestants from Catholics, to argue instead that what we should be doing is setting out a continuum of continuity with the medieval inheritance, and considering our typologies of the Reform movements against that. ${ }^{3}$ Then, as we teach the Christian Intellectual Tradition, we can see both genealogical and influential links across the eras and, I hope, present a better picture of what was going on in the Era of the Reformations and, through that, come to a greater understanding of the human condition.

\section{The Era of the Reformations, Re-Envisioned}

The old theory of the Reformations is that after a long period of deep darkness, in which Catholicism's lust for power had nearly drowned all true piety God sent an apostle, Martin Luther, to wake the church from darkness, and to shine the glorious light of the gospel on these corruptions through a dependence on the Holy Scriptures. This was an extraordinarily Protestant and not very historically accurate picture. But my point is not to examine the Roman Catholic and Protestant confessional historiographical divide again, but to examine this theory. If it was only the light of the gospel, why use non-scriptural traditional materials? Further, how did the Protestant Reformers' use the traditions that came to them from the medieval church?

\section{Winners Accepted Traditions, if Not Tradition}

In the Reformations, winners accepted traditions, if they did not wholly embrace Tradition. Speaking about winners and losers in the Reformations is crude, harkens too much to an us-vs.-them mentality we're supposed to have conquered, and doesn't allow for the sophisticated view of the Reformations that is so in vogue. But anyone who doesn't believe that there were winners and losers in the period of the Reformations is either ill-informed, or blind. The Peasant's War had losers, mostly lords and castles in the early period, followed by serious losses by the peasant bands. Dying in battle makes you a loser, surviving a battle makes you either a winner, or someone who still has a chance to become a winner. Zwingli lost the Second Battle of Kappel in 1531. The victorious Catholics took his body, burned it, and mixed the ashes with dung so as to keep it from being made into relics. This showed an astonishing lack of understanding of Protestant spirituality, but it also showed that they won. The anti-reform party lost in Münster, and then the followers of Jan of Leiden lost, and were horribly slaughtered. Huguenots lost in the St. Bartholomew's Day Massacre in 1572, and it was such a great loss that the Vatican struck a memorial medal. The English won against the Spanish Armada in 1588, and were able to maintain Elizabeth I on the throne, and their brand of middle way Protestantism in their realm. Protestants under Henry of Navarre won several battles against the forces of the Catholic League, a fact that no doubt helped set the stage for the promulgation of the Edict of Nantes in 1598, and to a great degree settled the French Wars of Religion.

Obviously, I've been speaking about military losses—which would be capped spectacularly in the Thirty Year's War that began near the centennial of Luther's 95 Theses. But the boundaries between the intellectual and physical worlds are always at best semi-permeable. Catholic forces lost the Disputation at Zurich, as well as the Second Disputation at Zurich. Catholic voices lost the battle for the religion of Geneva, and so were forced to convert or immigrate. Oecolampadius lost to Eck at the Disputation of Baden, and the quest for a united evangelical Switzerland was badly damaged. Conrad Grebel and

3 The literature investigating and supporting the thesis of continuity of the reform movements with the medieval world is vast. Significant volumes would include Oberman (1966); Oberman (1989), see especially Oberman (1994), see especially his discussion of the medieval mystical heritage, pp. 2-12 and (Cameron 1991), see his discussion of tradition, p. 89ff. 
his band lost the argument with the Zurich city fathers, and were forced to flee. Catholic preachers dominated the streets of Paris, and excited the crowds to view the Huguenots with fear and disgust. From Wittenberg to Prague, from Lausanne to Edinburgh, arguments were made about what was the true Christian religion.

There is no doubt that there were winners and losers in the period of the Reformations. What remains to be seen is what useful divisions we can make between those groupings. My point is that for Protestants, winning-and the consequent survival as a confessional group-was related to accepting a significant number of traditions, though generally not the theory or theology of Tradition. Those Protestant movements that thrived, that grew numerically, that took over territories, were those movements that avoided a radical primitivism in their return to the sources, and instead accepted the historical nature of the Christian witness and their own place in the passing down of Christianity from earlier to later generations. One example might suffice. Every school child who learns a date for the beginning of the Reformation learns 1517. There are a host of other possibilities-Steven Ozment even pushed the era of reform back to the mid-thirteenth century! (Ozment 1981). But again and again we return to Luther's posting of the 95 Theses on the door of the church in Wittenberg, whether he did so or not!

However, in the 95 Theses, Luther never suggested that the church did not have the power he sought to bridle. As Reformation documents go, it was thoroughly medieval. Luther sought to clarify, as in Thesis 20, where he stated, "Therefore the pope, in speaking of the plenary remission of all penalties, does not mean 'all' in the strict sense, but only those imposed by himself." (Dillenberger 1962, p. 492) Luther posted this in a church where the prince himself maintained an enormous collection of relics, and one of the reasons that prince did not allow the plenary indulgence to be preached in his realm was that he did not want the competition with his own relics. Traditional religion was everywhere in Wittenberg!

Perhaps a second example can help. Everyone who has studied the Reformations knows that Martin Luther said something like "Here I stand, I can do no other," before the Emperor Charles V, stating that he could not be moved without scripture's witness. Luther was kidnapped soon after that interview, and was secreted away to the Wartburg, a castle in Thuringia near the town of Eisenach. He had thundered at the pope that it was far past time to reform the church and the church's doctrines according to the plain sense of scripture. It's a stirring portrait, and we love it as much for the heroic character as for what it tells us about the history of the Reformations.

But during Luther's absence, things went awry in Wittenberg. Luther had himself convinced his senior colleague, Andreas Bodenstein von Karlstadt, to join the evangelical camp. In Luther's absence from Wittenberg, Karlstadt was able to take matters in his own hands, and he argued that, in removing error, tardiness was a sin. He pushed for a radical reformation of the worship that, he argued, was based on the scriptures. At Christmas, Karlstadt administered the Lord's Supper dressed in peasant's clothing, asking that he be called "Brother Andy," and giving both the bread and wine to the people. He denied the efficacy of images, and even called for their abolition from the churches in Wittenberg. All of these reforms, Karlstadt claimed, were scripturally based.

Wittenberg was in an uproar. Luther's prince, the Elector Frederick the Wise, was furious. Luther hurried back from the Wartburg and, after a brief time, preached a set of sermons, the Invocavit Sermons, that quelled the turbulence and brought peace back to Wittenberg. Our histories laud both the power of the preached word, and consider an important note on the shared role of the church and the prince to provide for the people. But it was Karlstadt who claimed to be following scripture! The plain sense arguments at the very least seem to support him. Jesus said, "All of you, drink of it." 4 The Decalogue rejected religious iconography, but only of those things that walk on the earth, or fly in the air, or swim in the water. ${ }^{5}$ That breadth impacted all religious iconography. Jesus instructed his

\footnotetext{
4 Matthew 26.27.

5 Exodus 20.4.
} 
disciples that they should not care about what they wore. ${ }^{6}$ All of Karlstadt's innovations or reforms were scripturally based.

But Karlstadt was the loser, and Luther the winner. We don't go visit our Scandinavian friends at the Evangelical Karlstadtian Church of America, or the stricter Karlstadtian Church, Missouri Synod. The Lutheran confession continued precisely because Luther found a meaningful compromise with the liturgical, doctrinal, and pastoral traditions that he inherited. If that is the case, then we must revise our grasp of the era of the Reformations, or the early modern period, on the grounds of far more continuity than change, on far more shared religion than prophetic jeremiad.

So, I will try to make my case on by examining two positive cases, that of Martin Luther and Lutherans after him, and of John Calvin. I'll add to that a negative case, that of the Anabaptist group around Conrad Grebel, the supporters of the Schleitheim Brotherly Union. It's also important to note what I'm trying to illustrate and what I'm not. By pointing out those confessions and movements that thrived in the sixteenth and seventeenth centuries, I am making an intellectual historian's judgment, not that of a theologian. I am in no way arguing that Lutherans or Calvinists or Anglicans were better Christians. That's a different argument for a different day. What I'm trying to ascertain is whether their shared survival and expansion can be correlated to a particular historical choice that, while not accidental in the sense of human willing, is absolutely accidental in an Aristotelian sense.

\section{Martin Luther and Lutheran Tradition}

Martin Luther stood before Charles V and said, “Unless I am convinced by the testimony of the Scriptures or by clear reason (for I do not trust either in the pope or in councils alone, since it is well known that they have often erred and contradicted themselves), I am bound by the Scriptures I have quoted and my conscience is captive to the Word of God. I cannot and will not recant anything, since it is neither safe nor right to go against conscience. Here I stand, I can do no other. May God help me. Amen." (Brecht 1985-1993). It's a scene almost made for a heroic epic or movie. It's heroic, and it fits the crusading piety of a religious hero that many still want to believe. But does it accurately describe Luther's work? In his attacks on the peasants and the Jews, Luther ignored the scriptural prohibitions on violence in the New Testament..$^{7}$ Against the Robbing and Murdering Hordes of Peasants was harsh, inspired by Luther's personal trip into Thuringia, where he viewed firsthand the depredations of the rebels (Luther 1955-1986; Luther 1883-2002). This treatise encouraged all who would come upon them to "smite, slay, and stab" the rebels. ${ }^{8}$ In his An Open Letter on the Harsh Book against the Peasants in August of that same year, Luther did not attempt to apologize for his vehemence, only to explain it. ${ }^{9}$ His 1543 treatise The Jews and their Lies continued this strain ${ }^{10}$. In it, Luther advised that the synagogues should be burned, Jewish houses be destroyed, Jewish holy books be confiscated, rabbis forbidden to teach, Jews be prohibited from the safe passage on public roads, the occupation of money-lending be denied to Jews, and Jews be forced to do manual labor for their livings. Luther had given up on converting Jews by kind words, and wanted to force conversions by making life impossible for members of this minority religion, paying no attention to scriptural demands to take care of the neighbor, even one of a hated religion. ${ }^{11}$ We can say that Luther was a man of his time, but that is simply another way of saying that he accepted the ecclesiastical and cultural traditions he inherited. A more sympathetic reading of Luther might argue that he read the Sermon on the Mount as a personal

\footnotetext{
Matthew 6.28

Matthew 26.52; Matthew 5.44; etc.

LW 46.50. WA 18.359.

LW 46.57-86. WA 18.384-401.

10 LW 47.121-306. Roland Bainton opined that it was unfortunate that Luther had not died before writing the treatise (Bainton 1950). A modern example comes from James McNutt, who even in the midst of setting forth the plain facts about Luther's anti-semitism, seeks to find threads in Luther's theology from which a compensatory ecumenical theology could be built. See (McNutt 2011).

11 Luke 10.25-37.
} 
rather than corporate ethic, following a tradition that stretched back at least to Augustine. But that observation merely supports the thesis from a different angle, as it demonstrates Luther's formation in and acceptance of a persecuting culture.

After Luther's death, the tendency toward adoption of the traditions of medieval Christianity only strengthened. A good example is the struggle between Lutherans and Calvinists in the Palatinate. The disastrous Schmalkaldic War, and the consequent Augsburg and Leipzig Interims, demonstrated the fissures that existed within the formerly solid appearance of the edifice of Lutheranism. It was that divided German evangelical world into which Calvinism originally entered, through the flights of refugees who settled in Aachen, Metz, Trier, Emden and Bremen, in the 1560s (Brady, Jr. 2009, p. 252). Various princes accepted the faith, converting frequently, though not always, from Lutheranism. This movement is sometimes called the Second German Reformation, and it peaked in the early 1590s. ${ }^{12}$ Moreover, according to Thomas A. Brady, "The faith presented itself to the German lands as not a new faith but an enhancement and extension of Luther's reformation. Luther's heirs thought differently" (Brady, Jr. 2009, p. 253). Moreover, "Lutherans gagged at the Calvinist requirement of leavened bread in the Lord's Supper; Calvinists fumed at Lutherans' attachment to so many rags and tags of defeated 'popery'" (Brady, Jr. 2009, p. 254). This struggle did not stop at expressions of discontent with the religious habits of the other confessions. Power struggles for control of territories could and did result in the loss of ministerial positions, banishment, and even the loss of life (Jürgens 2013). Reformed thinkers viewed the Lutheran belief in the local presence in the Lord's Supper, the exorcism rite in the baptismal service, church art, liturgical vestments, and a church calendar that retained the Marian festivals as examples of papal religion that had been retained, and needed to be purified away (Nischan 2000). Notably, the Calvinist arguments depended upon the priority of scripture over tradition. But Lutheran belief and cult was a popular movement that had been well established, and one that depended upon a continuity with the liturgical and doctrinal traditions of the medieval church.

\section{John Calvin and Tradition}

While a great amount of effort has been spent on whether Calvin was the progenitor of that which came after him-Protestant scholasticism—far less has effort has been expended on Calvin's relationship to the antecedent tradition, especially the traditions of the medieval church. But Calvin's engagement with the Christian tradition was rich, a career-spanning effort that saw significant change. While we cannot trace every bit of that, some examples can suffice. For instance, Calvin used the tradition in his biblical interpretive work. He used the patristic sources not just as sparring partners, but as authoritative guides to the true interpretations (Holder 2006). While he did not slavishly follow the interpretations of his authorities, neither did he set them aside lightly. Frequently, the questions that he chose to answer in his commentaries were those that the tradition of commenting had set as important (Thompson 2007; Steinmetz 1990; Steinmetz 1991). Calvin used the tradition in his systematic doctrinal work. At times, Calvin added citations from the fathers and medievals that did not even add to his case, or to the argument. Unless we wish to argue that he was acting like a Ph.D. candidate, scurrying along and putting in a footnote to every possible source to prove that he had read it, the most likely reason for Calvin engaging in such a practice was to add theological authority to his own work (Holder 2009). This was the argument from authority, a normal facet of medieval theological dialectic. Calvin regularly sought the imprimatur of his favorite orthodox theologians, including Augustine, Ambrose, Chrysostom, and Bernard.

But Calvin's engagement with the orthodox doctrinal tradition did not end there. Beyond the framework and the development of his thought, Calvin even went so far as to use the theological

12 But see, Klueting (2004)—which argues that the term "second Reformation" is worse than unhelpful. 
tradition for the substance of his doctrine. ${ }^{13}$ A fascinating instance comes from Calvin's consideration of infant baptism. It appeared in the midst of a full-throated attack on the power of tradition that Calvin published in 1549, the Adultero-German Interim. ${ }^{14}$ This was Calvin's response to the Augsburg Interim of 1548, and Calvin's attack upon it was as devastating as that of any Lutheran. But Calvin included an interesting side-note in his destruction of the Roman model of unwritten traditions. He noted that his opponents adduced "a plausible example in the Baptism of Infants; but as there is no fiction too gross or childish to be vended in the Papacy under the name of Tradition, whosoever has not the caution to keep out of this trap, voluntarily entangles himself in all kinds of superstition."15 What attracts our attention is what Calvin gave up-the Romanists have a plausible example in pedobaptism as coming from the tradition of the church. They argued this on the basis of the lack of specific New Testament scriptural witness to any instance of infant baptism. Calvin, after introducing the issue of tradition, would argue that all sacraments were founded on the scripture, and that all the ancients knew that infant baptism was licit, ignoring the counter examples in Tertullian and Gregory of Nazianzus. ${ }^{16}$ One wonders why he mentioned it at all.

The careful observer can see that Calvin immersed himself in the Church's theological tradition, setting the framework for his argumentation, and framing the questions that Calvin believed had to be answered, either in exegeting a passage of scripture, or in considering the impact of a particular doctrine in a theological or pastoral complex. Finally, the tradition sometimes was the substance of Calvin's argument-and a part of his mind was aware of both the possibilities and dangers that lay therein. But there can be no doubt that Calvin formed his reforms through a selective intentional engagement with and harvest from the medieval and early traditions.

\section{The Anabaptists and Medieval Tradition}

The list of those who engaged the medieval tradition only extends further. Anglicanism became impossible to understand without the concept of a via media. Doctrinal constructs that had been forged on the anvils of councils and conflicts were not abandoned, whether there was "adequate" scriptural support for them or not, prescinding at all times from settling the question of what "adequate" scriptural support would be, and who served as the arbitrator who determined that the canon had been reached.

One ill-defined group that certainly did not meet the standard of being traditional enough was the Anabaptists. This loose conglomeration of spiritual leaders, primitivist theorists, and dedicated followers never gained large numerical following. George Huntston Williams' system of dividing the Protestant camps into magisterial Reformers and radical Reformers avoided the question of what held Anabaptists together with Spiritualists and Anti-Trinitarians, and saw a common purpose in their rejection of working with the organs of the early modern state or realm. But our typology may fit them even better.

By 1525, the Swiss Brethren had already attempted to interest Huldrych Zwingli in their more thoroughgoing reform based on pure biblical models. Failing that, and under suspicion from the Zurich city council, on 21 January 1525, George Blaurock was baptized by Conrad Grebel in Zurich. He was a close friend of the first Anabaptist martyr, Felix Manz, who was executed by drowning in

13 Randall Zachman has seen this in Calvin's expanding use of the laying on of hands in ordination services (Zachman 2007). Zachman argues for what he termed an " ... increasing catholicity in the development of Calvin's theology." (p. 437) While Zachman's analysis was concentrating upon Calvin's expanding use of visual symbols, I believe that my own analysis of an increasing dependence on the orthodox theological tradition is a parallel development.

14 Published in 1549, CO 7.545-686. Interim Adultero-Germanum: Cui Adiecta Est Vera Christianae Pacificationis Et Ecclesiae Reformandae Ratio.

15 CO 7.614. "Plausibile quidem exemplum adducunt in baptismo parvulorum, sed quum nullum sit tam crassum aut puerile commentum, quod non traditionis nomine venditetur in papatu, omni superstitionum genere ultro se implicat, quisquis ab hac captione sibi non cavet."

16 Tertullian, De Baptismo, 18, and Gregory of Nazianzus, Or. 40, De Baptismo. 
the Limmat on 5 January 1527. The Anabaptists sought a biblical primitivism previously unseen in the era of the Reformations. The confession they would write in 1527, The Schleitheim Brotherly Union, that Calvin, Zwingli, Oecolampadius, Haller and other reported as representative of Anabaptism, sought to argue that its roots in scripture and against the practices of the pope and libertines were what freed people to serve Christ. ${ }^{17}$

The various Anabaptist groups never reached the numerical strength of the Lutheran, Reformed, or Anglican bodies. It was unthinkable that they could ever be a state church, so the process of growth by birth in a region was foreclosed to them. Further, they took the fact of their numerical inferiority as a mark of the truth of their confession. Anna Jansz, on the way to her own execution by drowning in 1539, instructed her son through her will, that said, in part, "I urge you, my son, submit to the yoke of Christ; endure it willingly; for it is a great honour and joy. Do not follow the majority of the people, but when you hear about a poor, simple, repudiated handful of men and woman cast out of the world, join them. Do not be ashamed to confess your faith. Do not fear the majority of the people. It is better to let go of your life than deviate from the truth." ${ }^{18}$ In a parallel that has always puzzled me, much like Socrates, Jansz identified the majority with trouble. Perhaps the shared experience of being executed makes connections that historians have a difficult time tracing.

If there is a group in the early modern period that fulfills the dictum scripture vs. tradition, it would be the Anabaptists. Their strict communitarian religion demanded rejection of the sword and infant baptism, because of the text of the New Testament. ${ }^{19}$ This put them at odds with the temporal realms of their day, and the fusion of the sacred and secular which was so much a part of the early modern world. This so horrified Holy Roman Empire that, at the Diet of Speyer in 1529, one of the few topics on which Lutherans and Catholics could agree was the necessity of executing Anabaptists.

\section{Getting to the Roots of the Problem}

So I've argued for an eschewal of the tried and true scripture vs. tradition formulation in favor of seeing the various reforming groups on a continuum of engagement and acceptance with the shared inheritance of the medieval and patristic tradition. ${ }^{20}$ Obviously, there will be outliers, the various groups of Anabaptists and Radicals being the paradigmatic examples. But they will serve as either the example of what happened when one took things too far, or as the exception that proves the rule, or the illustration of the fixed boundary. But that leaves a significant hole in my theory. Historiographically, if this is as clear as I'm arguing, why have so many thinkers before taken the other tack? ${ }^{21}$ And the obvious answer is, because the Reformers said so. Luther attacked tradition. Calvin attacked tradition. Cranmer, Knox, Karlstadt, Melanchthon, Beza, Musculus, Bucer, and Oecolampadius attacked tradition. All did so in order to place Christian doctrine and practice upon the clear foundation of the written word of the scriptures.

But do we have to accept what they said at face value? What if their categorical denial of the power of tradition was actually relative and contextually fraught? The great exponent of the Church's tradition in the twentieth century has been Yves Congar, who argued that throughout history there was a theological source, the apostolic deposit, that was uniquely recognized and wielded by the magisterium, and especially the pope. Congar would go so far as to approve of Pope Pius IX's statement

17 See Yoder's introduction to Schleitheim in (Sattler 1973).

18 Quoted in (Haude 2000).

9 Schleitheim, paragraphs 1 \& 6. in (Sattler 1973).

20 Recent analysts have continuted to assert an acceptance of the thesis of the early modern period's continuity with the prior medieval tradition. Some examples are Terpstra (2015), depends upon the models of the medieval from R. I. Moore, Benedict Anderson, and Guido Ruggiero. (Wiesner-Hanks 2008), states bluntly that " . . in many aspects of life, continuities outweighed change." (p. 9). Thomas A. Brady, Jr., orients his study by beginning with the medieval inheritance, whether canonical, cultural, or imagined (Brady, Jr. 2009).

21 See (among others), (Walker 1985, p. 428; Smith 1930, p. 279; Bainton 1952, p. 42; Ozment 1975, pp. 148ff; Eire 2016, p. 173; Matheson 2007, pp. 275-76; MacCulloch 2004, pp. 97-98; Wandel 2011, pp. 112-13; Lindberg 2010, p. 82; Dickens et al. 1985, p. 36; Cameron 1991, pp. 139ff; Hillerbrand 2007, pp. 52-53). 
that he was the tradition. This argument, in its early form, was defended by John Driedo, Melchior Cano, Nicholas of Cusa, and Alphonsus de Castro. This was the "tradition" that the Reformers sought to tame, and that which Congar would call "Tradition-capital T."

But in the modern age, we speak of Tradition and traditions. To borrow Congar's useful delineation, "traditions" (small $t$ ) are those habits of mind and pieces of received wisdom that the church constantly passes down to the next generation; "Tradition" (capital T) is the power of the Church, based on a conveniently oral source, to proclaim authority in the manner it saw fit. The inheritance of the prior fifteen centuries, the Reformers argued both implicitly and explicitly, was the common birthright of Christians across Europe, and did not belong to the Church any more than it belonged to the prince, or any of the ranks of society. To say otherwise was to suggest that history was not available to all, but that it was malleable at the desire of a privileged few.

The Reformers sought to deny Tradition, while accepting and controlling traditions. They had their detractors, from the left in the Anabaptists who attempted to recreate the church of the New Testament and in heretics like Miguel de Servet who argued on the basis of the New Testament texts that the trinity simply could not be found in the world of the early church. They had their detractors as well on the right, with Catholics asking, "Where was your church before Luther?" But as creators of institutions, access to fifteen centuries of traditions generally stood the various reforming movements in good stead, though there was always the question of what was enough.

So, why is that important to us as teachers of the Christian Intellectual Tradition? First, considering the reforming movements of the early modern period as being on a continuum of engagement with the inherited traditions, rather than dropping tradition for the purity of scripture, is simply better history. From Luther to Zwingli to Calvin to Cranmer to Vermigli to Knox to Ursinus to whomever, time and again we see practices and doctrines being accepted from the medieval heritage. To give a particular case, Lutheran doctrine on the presence of Christ in the eucharist stayed so close to the medieval heritage that, in the twentieth century, Karl Rahner declared that both confessions accepted the unambiguous words of Scripture concerning the real presence (Rahner 1961). The Reformers took over traditions, and to argue otherwise involves historians in an attempt to bend history to justify doctrine.

Second, this insight might create a better typology of reform movements than some we presently use. The magisterial-Radical typology raises the church's relationship to the state to the zenith of importance. But very few thinkers in the sixteenth century believed that their church was under the thumb of the prince, and many princes bemoaned that very fact. A different typology that considers continuity with received traditions as the gauge to be measured might have the increased value of being able to place all of the large ecclesiastical and ecclesiological reform movements of the era together, and rate them on a continuum, helping us to understand them better.

Finally, it is worthwhile in this postmodern age to consider not only our objects of study, but ourselves as the analysts. In 1960, Hans-Georg Gadamer published the first edition of his Truth and Method, and the world of hermeneutics would never be the same. While it has enjoyed significance in a number of fields, for our purposes today it is enough to say that it has shifted the modern notion of tradition. Gadamer argued that all people have a historically-effected consciousness (wirkungsgeschichtliches Bewußtsein); thus, all people are living in a historical stream of tradition that helps to define them. This description of historically-situated existence nicely parallels what I'm describing in the argument for Reformers engaging "tradition." All the Reformers, whether Lutheran, Catholic, Reformed, Radical or Anglican, received the Christian Intellectual Tradition of fifteen centuries, along with traditions of worship, piety, and a sense of how those complexes fit together with the rest of society. By examining what they did with their mental and emotional inheritance, we will go much further in our understanding of them, and in our own efforts at making progress on understanding the human condition. As scholars, but even more so as teachers of the Christian Intellectual Tradition, that is a worthy goal.

Conflicts of Interest: The authors declare no conflict of interest. 


\section{References}

Bainton, Roland. 1950. Here I Stand: A Life of Martin Luther. Nashville: Abingdon Press, p. 379.

Bainton, Roland. 1952. The Reformation of the Sixteenth Century. Boston: Beacon Press.

Benedict, Philip. 2002. Christ's Churches Purely Reformed. New Haven: Yale University Press.

Brady, Jr., Thomas A. 2009. German Histories in the Age of the Reformations, 1400-1650. Cambridge: Cambridge University Press.

Brecht, Martin. 1985-1993. Martin Luther. Translated by James L. Schaaf. Philadelphia: Fortress Press, p. 460.

Calvin, John. 1960. Institutes of the Christian Religion. 2 Vols. Translated by Ford Lewis Battles. Edited by John T. McNeill. Philadelphia: Westminster Press, p. viii.8.

Calvin, John. 1895. Opera Quae Supersunt Omnia. 59 Vols. Edited by Wilhelm Baum, Edward Cunitz and Edward Reuss. Brunswick: Schwetschke and Sons.

Cameron, Euan. 1991. The European Reformation. Oxford: Oxford University Press.

Dickens, Arthur Geoffrey, John M. Tonkin, and Kenneth Powell. 1985. The Reformation in Historical Thought. Cambridge: Harvard University Press.

Dillenberger, John. 1962. Martin Luther: Selections From His Writings. New York: Doubleday, p. 492.

Eire, Carlos M. N. 2016. Reformations: The Early Modern World 1450-1650. New Haven: Yale University Press.

George, Timothy. 2011. Reading Scripture with the Reformers. Grand Rapids: IVP Academic, pp. 17-18.

Haude, Sigrun. 2000. Anabaptism. In The Reformation World. Edited by Andrew Pettegree. London: Routledge, p. 237.

Hillerbrand, Hans J. 2007. The Division of Christendom: Christianity in the Sixteenth Century. Louisville: Westminster John Knox Press.

Holder, R. Ward. 2006. John Calvin and the Grounding of Interpretation: Calvin's First Commentaries. Leiden: Brill, pp. 111-24.

Holder, R. Ward. 2009. Calvin and Tradition: Tracing Expansion, Locating Development, Suggesting Authority. Toronto Journal of Theology 25: 215-26. [CrossRef]

Jürgens, Henning P. 2013. Intra-Ptorestant Conflicts in 16th Century Poland and Prussia-The Case of Benedict Morgenstern. In Calvin and Luther: The Continuing Relationship. Edited by R. Ward Holder. Göttingen: Vandenhoeck \& Ruprecht, pp. 143-64.

Klueting, Harm. 2004. Problems of the Term and Concept 'Second Reformation': Memories of a 1980s Debate. In Confessionalization in Europe, 1555-1700: Essays in Honor and Memory of Bodo Nischan. Edited by John M. Headley, Hans J. Hillerbrand and Anthony J. Papalas. Burlington: Ashgate, pp. 39-49.

Lindberg, Carter. 2010. The European Reformations, 2nd ed. Malden: Wiley-Blackwell.

Luther, Martin. 1883-2002. D. Martin Luthers Werke: Kritische Gesamtausgabe. 69 Vols. Weimar: Hermann Böhlau, vol. 18, pp. 357-61.

Luther, Martin. 1955-1986. Luther's Works, American Edition. Edited by Jaroslav Pelikan and Helmut Lehmann. Philadelphia and St. Louis: Concordia, vol. 46, pp. 45-56.

Luther, Martin. 1962. Freedom of a Christian. In Martin Luther: Selections from his Writings. Edited by John Dillenberger. Garden City: Anchor Books, p. 50.

MacCulloch, Diarmaid. 2004. The Reformation. New York: Viking.

Matheson, Peter, ed. 2007. Reformation Christianity. In A People's History of the Church. Minneapolis: Fortress.

McNutt, James. 2011. Luther and the Jews Revisited: Reflections on a Thought Let Slip. Currents in Theology and Mission 38: 40-47.

Nischan, Bodo. 2000. Germany after 1550. In The Reformation World. Edited by Andrew Pettegree. London: Routledge, p. 402.

Heiko Oberman, ed. 1966. Forerunners of the Reformation: The Shape of Late Medieval Thought. New York: Holt, Rinehart and Winston.

Oberman, Heiko. 1989. Luther: Man between God and the Devil. Translated by Eileen Walliser-Schwarzbart. New Haven: Yale University Press.

Oberman, Heiko. 1994. The Longed-For Reformation; Dennis Tamburello. In Union with Christ: John Calvin and the Mysticism of St. Bernard. Louisville: Westminster John Knox Press.

Ozment, Steven. 1975. The Reformation in the Cities: The Appeal of Protestantism to Sixteenth-Century Germany and Switzerland. New Haven: Yale University Press. 
Ozment, Steven. 1981. The Age of Reform, 1250-1550: An Intellectual and Religious History of Late Medieval and Reformation Europe. New Haven: Yale University Press.

Rahner, Karl. 1961. Theological Investigations. 21 Vols. Baltimore: Helicon Press, vol. 4, pp. 287-311.

Sattler, Michael. 1973. The Legacy of Michael Sattler. John H. Yoder, trans. and ed. Scottdale: Herald Press, pp. 32-34. Smith, Preserved. 1930. A History of Modern Culture. New York: Henry Holt.

Steinmetz, David. 1990. Calvin and the Patristic Exegesis of Paul. In The Bible in the 16th Century. Edited by David Steinmetz. Durham: Duke University Press, pp. 100-18.

Steinmetz, David. 1991. Calvin among the Thomists: Exegesis of Romans. In Biblical Hermeneutics in Historical Perspective. Edited by Mark Burrows and Paul Rorem. Grand Rapids: Eerdmans, pp. 198-214.

Tavard, George. 1959. Holy Writ or Holy Church: The Crisis of the Protestant Reformation. London: Burns and Oates.

Terpstra, Nicholas. 2015. Religious Refugees in the Early Modern World: An Alternative History of the Reformation. Cambridge: Cambridge University Press.

Thompson, John. 2007. Reading the Bible with the Dead: What You Can Learn from the History of Exegesis that You Can't Learn from Exegesis Alone. Grand Rapids: Eerdmans.

Vanhoozer, Kevin. 2016. Biblical Authority after Babel: Retrieving the Solas in the Spirit of Mere Protestant Christianity. Grand Rapids: Brazos Press.

Walker, Williston. 1985. A History of the Christian Church, 4th ed. New York: Scribners.

Wandel, Lee Palmer. 2011. The Reformation: Towards a New History. Cambridge: Cambridge University Press. Wiesner-Hanks, Merry. 2008. Women and Gender in Early Modern Europe, 3rd ed. Cambridge: Cambridge University Press. Zachman, Randall. 2007. Image and Word in the Theology of John Calvin. South Bend: University of Notre Dame Press, pp. 313-17.

(C) 2017 by the author. Licensee MDPI, Basel, Switzerland. This article is an open access article distributed under the terms and conditions of the Creative Commons Attribution (CC BY) license (http://creativecommons.org/licenses/by/4.0/). 